\title{
The "neutral" community structure of planktonic herbivores, tintinnid ciliates of the microzooplankton, across the SE Tropical Pacific Ocean
}

\author{
J. R. Dolan ${ }^{1}$, M. E. Ritchie ${ }^{2}$, and J. $\operatorname{Ras}^{3}$ \\ ${ }^{1}$ Marine Microbial Ecology Group, Laboratoire d'Océanographie de Villefranche, Université Paris6 CNRS UMR 7093, BP \\ 28, Station Zoologique, 06230 Villefranche-sur-Mer, France \\ ${ }^{2}$ Syracuse University, Department of Biology, 108 College Place, Syracuse NY 13244, USA \\ ${ }^{3}$ Marine Optics and Remote Sensing Group, Laboratoire d'Océanographie de Villefranche, Université Paris6 CNRS UMR \\ 7093, 06230 Villefranche-sur-Mer, France
}

Received: 5 February 2007 - Published in Biogeosciences Discuss.: 13 February 2007

Revised: 7 May 2007 - Accepted: 23 May 2007 - Published: 7 June 2007

\begin{abstract}
We assessed the community characteristics of a group of planktonic herbivores across a species-rich area, the SE Pacific Ocean. A series of 22 stations between the Marquise Islands $\left(7^{\circ} \mathrm{S} 142^{\circ} \mathrm{W}\right)$ and the coast of Chile $\left(35^{\circ} \mathrm{S}\right.$ $73^{\circ} \mathrm{W}$ ) was sampled during the BIOSOPE cruise in 2004. We examined the relationships between taxonomic diversity, morphological diversity, patterns of tintinnid species assemblage, and phytoplankton abundance. Tintinnid community characteristics were estimated from large volume (20$601)$ discrete depth sampling and phytoplankton were characterized based on HPLC pigment signatures. Across the transect, average water column concentrations of tintinnids ranged from $2-40$ cells $^{-1}$ or $8-40 \mathrm{ng} \mathrm{Cl}^{-1}$, and were positively related to chlorophyll $a$ concentrations which varied between $0.07-2 \mu \mathrm{gl}^{-1}$. Large numbers of tintinnid taxa were found, 18-41 species per station, yielding a total of 149 species. Among stations, morphological and taxonomic diversity metrics co-varied but were not significantly related to phytoplankton diversity estimated using a pigment-based size-diversity metric. Taxonomic diversity of tintinnids, as H' or Fishers' alpha, was inversely related to chlorophyll concentration and positively to the depth of the chlorophyll maximum layer. Species abundance distributions were compared to geometric, log-series and log-normal distributions. For most stations, the observed distribution most closely matched log-series, coherent with the neutral theory of random colonization from a large species pool. Occurrence rates of species were correlated with average abundance rather than specific characteristics of biomass or lorica oral diameter (mouth) size. Among stations, species richness was cor-
\end{abstract}

Correspondence to: J. Dolan

(dolan@obs-vlfr.fr) related with both the variety of mouth sizes (lorica oral diameters) as well as numbers of species per mouth size, also consistent with random colonization.

\section{Introduction}

In the early 20th century, oceanographic and biological surveys identified the SE Pacific as extraordinarily species-rich (e.g., the Agasizz Expedition of 1904-1905 and the Carnegie Expedition of 1928-1929). With the decline of survey campaigns, the zone was very rarely sampled (Hasle, 1959). The few modern research efforts or major programs in the SE Pacific (such as EastroPac in the late 1960's), in common with other oceanic areas, were process studies, focused on parameters such as biomass estimates and rate measures of primary and secondary production. Interestingly, from these studies a paradigm has emerged stressing the apparent efficiency of tropical and subtropical food webs. Algal biomass is quite low, occasionally lower than one might expect given concentrations of nutrients (i.e., zones of high nutrient low chlorophyll, HNLC) and nearly all the primary production is consumed. The efficiency of grazers, especially protists, is often invoked as an explanation, at least partial (e.g., Leising et al. 2003) for the maintenance of low algal biomasses. The efficiency of both primary producers and secondary consumers may be related to the diversity of tropical and subtropical pelagic systems. However, the existence or importance of the link between trophic efficiency and diversity in planktonic communities is difficult to evaluate because community characteristics have received very little attention, especially with regard to the primary consumers, the microzooplankton.

Published by Copernicus Publications on behalf of the European Geosciences Union. 
Table 1. Station locations and tintinnid sampling. Cruise track shown in Fig. 1. Layer denotes depth layer sampled in meters, $n(Z)$ the number of discrete depth sampled within the layer and $\sum$ Vol the total volume (1) screened through a $20 \mu \mathrm{m}$ mesh plankton concentrator.

\begin{tabular}{lccccc}
\hline Station & Location & Date & Layer & $n(Z)$ & $\sum$ Vol \\
\hline SE3 & $9^{\circ} 56^{\prime} \mathrm{S} 142^{\circ} 15^{\prime} \mathrm{W}$ & $10 / 25 / 04$ & $15-70$ & 2 & 10 \\
MAR1 & $8^{\circ} 22^{\prime} \mathrm{S} 141^{\circ} 15^{\prime} \mathrm{W}$ & $10 / 27 / 04$ & $15-80$ & 4 & 20 \\
HLN1 & $9^{\circ} 00^{\prime} \mathrm{S} 136^{\circ} 52^{\prime} \mathrm{W}$ & $11 / 01 / 04$ & $5-140$ & 6 & 30 \\
STB1 & $11^{\circ} 45^{\prime} \mathrm{S} 134^{\circ} 05^{\prime} \mathrm{W}$ & $11 / 03 / 04$ & $5-140$ & 6 & 30 \\
STB2 & $13^{\circ} 31^{\prime} \mathrm{S} 132^{\circ} 08^{\prime} \mathrm{W}$ & $11 / 04 / 04$ & $5-130$ & 4 & 20 \\
STB3 & $15^{\circ} 30^{\prime} \mathrm{S} 129^{\circ} 54^{\prime} \mathrm{W}$ & $11 / 05 / 04$ & $5-130$ & 5 & 25 \\
STB4 & $17^{\circ} 13 \mathrm{~S} 127^{\circ} 57^{\prime} \mathrm{W}$ & $11 / 06 / 04$ & $5-210$ & 6 & 30 \\
STB6 & $20^{\circ} 25^{\prime} \mathrm{S} 122^{\circ} 55^{\prime} \mathrm{W}$ & $11 / 08 / 04$ & $5-250$ & 6 & 30 \\
STB8 & $23^{\circ} 31^{\prime} \mathrm{S} 117^{\circ} 51^{\prime} \mathrm{W}$ & $11 / 10 / 04$ & $5-240$ & 6 & 58 \\
GYR2 & $26^{\circ} 01^{\prime} \mathrm{S} 114^{\circ} 01^{\prime} \mathrm{W}$ & $11 / 13 / 04$ & $5-270$ & 6 & 60 \\
STB11 & $27^{\circ} 45^{\prime} \mathrm{S} 107^{\circ} 16^{\prime} \mathrm{W}$ & $11 / 20 / 04$ & $5-300$ & 5 & 25 \\
STB12 & $28^{\circ} 30^{\prime} \mathrm{S} 104^{\circ} 16^{\prime} \mathrm{W}$ & $11 / 21 / 04$ & $5-280$ & 6 & 60 \\
STB13 & $29^{\circ} 12^{\prime} \mathrm{S} 101^{\circ} 284 \mathrm{~W}$ & $11 / 22 / 04$ & $5-230$ & 6 & 60 \\
STB14 & $30^{\circ} 01^{\prime} \mathrm{S} 98^{\circ} 23^{\prime} \mathrm{W}$ & $11 / 23 / 04$ & $5-230$ & 6 & 56 \\
STB15 & $30^{\circ} 46^{\prime} \mathrm{S} 95^{\circ} 26^{\prime} \mathrm{W}$ & $11 / 24 / 04$ & $5-175$ & 6 & 60 \\
EGY2 & $31^{\circ} 50^{\prime} \mathrm{S} 91^{\circ} 27^{\prime} \mathrm{W}$ & $11 / 26 / 04$ & $5-190$ & 6 & 35 \\
STB17 & $32^{\circ} 23^{\prime} \mathrm{S} 86^{\circ} 47^{\prime} \mathrm{W}$ & $12 / 01 / 04$ & $5-175$ & 6 & 55 \\
STB18 & $32^{\circ} 41^{\prime} \mathrm{S} 84^{\circ} 04^{\prime} \mathrm{W}$ & $12 / 02 / 04$ & $5-140$ & 6 & 54 \\
STB20 & $33^{\circ} 21^{\prime} \mathrm{S} 78^{\circ} 06^{\prime} \mathrm{W}$ & $12 / 04 / 04$ & $5-140$ & 6 & 60 \\
STB21 & $33^{\circ} 38^{\prime} \mathrm{S} 75^{\circ} 50^{\prime} \mathrm{W}$ & $12 / 05 / 04$ & $5-90$ & 6 & 60 \\
UPW2 & $33^{\circ} 52^{\prime} \mathrm{S} 73^{\circ} 32^{\prime} \mathrm{W}$ & $12 / 07 / 04$ & $0-50$ & 6 & 60 \\
UPX2 & $34^{\circ} 38^{\prime} \mathrm{S} 72^{\circ} 78^{\prime} \mathrm{W}$ & $12 / 10 / 04$ & $0-60$ & 6 & 39 \\
\hline
\end{tabular}

These grazers have long been identified as the likely dominant consumers of algal production, given their relatively high biomass compared to metazoan grazers, especially in systems such as the SE Pacific (Beers and Stewart, 1971). Here we focus on large-scale geographic patterns across the SE Pacific Ocean for a particular group of these organisms members of the ciliate suborder Tintinnia, tintinnid ciliates of the microzooplankton, which are united ecologically as grazers on pico and nanplankton.

Tintinnid ciliates are characterized by the possession of a tube or vase-shaped shell or lorica into which the ciliate cell can contract. They are generally a minority component of the microzooplankton, representing 5-10\% of ciliate numbers (e.g., Dolan and Marassé, 1995) but occasionally dominate the microzooplankton (Karayanni et al., 2005). Tintinnids, as loricate choreotrich ciliates, are considered a monophyletic group in traditional ciliate classification schemes (Lynn and Small, 2000) and based on results of molecular work (e.g., Agatha and Strüder-Kypke, 2007; Agatha et al., 2005; Snoeyenbos-West et al., 2002). The group is speciesrich with over 700 species distinguished in the monographs of Kofoid and Campbell (1929, 1939), a large portion of which (>200) were newly described from samples gathered during the Agassiz expedition to the Pacfic.

Similar to foraminifera and radiolarians, species descriptions have been based on skeletal or shell (lorica) architecture. However, species in some genera are known to be polymorphic (e.g. Laval-Peuto, 1983; Williams et al., 1994).
Characteristics of the lorica are not only of taxonomic but also ecological significance. The diameter of the mouth end of the lorica, the lorica oral diameter (LOD), is related to the size of the food items ingested by the ciliate. Heinbokel (1978) noted that the largest prey ingested were about half the LOD and Dolan et al. (2002) found that tintinnid feeding rates were maximal on prey sizes equal to about $25 \%$ of LOD. Thus, in tintinnid ciliates the lorica distinguishes species both taxonomically and ecologically. Not surprisingly then, morphological diversity, in terms of LOD sizes, and taxonomic diversity co-vary both spatially and temporally.

Between the Moroccan upwelling system and the Eastern Mediterranean, taxonomic and morphological diversity of tintinnids showed parallel trends (Dolan et al., 2002). Diversity increased from the upwelling area into the Western Mediterranean and declined slightly towards the oligotrophic Eastern Mediterranean. Both taxonomic and morphological (LOD) diversity were correlated with a chlorophyll sizediversity estimate. In temperate systems, seasonal changes in the average LOD of tintinnid communities are well-known (e.g., Verity, 1987). In a recent study of the seasonal changes in a tropical lagoon, median LOD of the tintinnid community shifted with the fraction of chlorophyll $a>10 \mu \mathrm{m}$ (Dolan et al., 2006). The numbers of species were relatable to numbers of LOD size-classes and taxonomic diversity was correlated with LOD size-class diversity. 


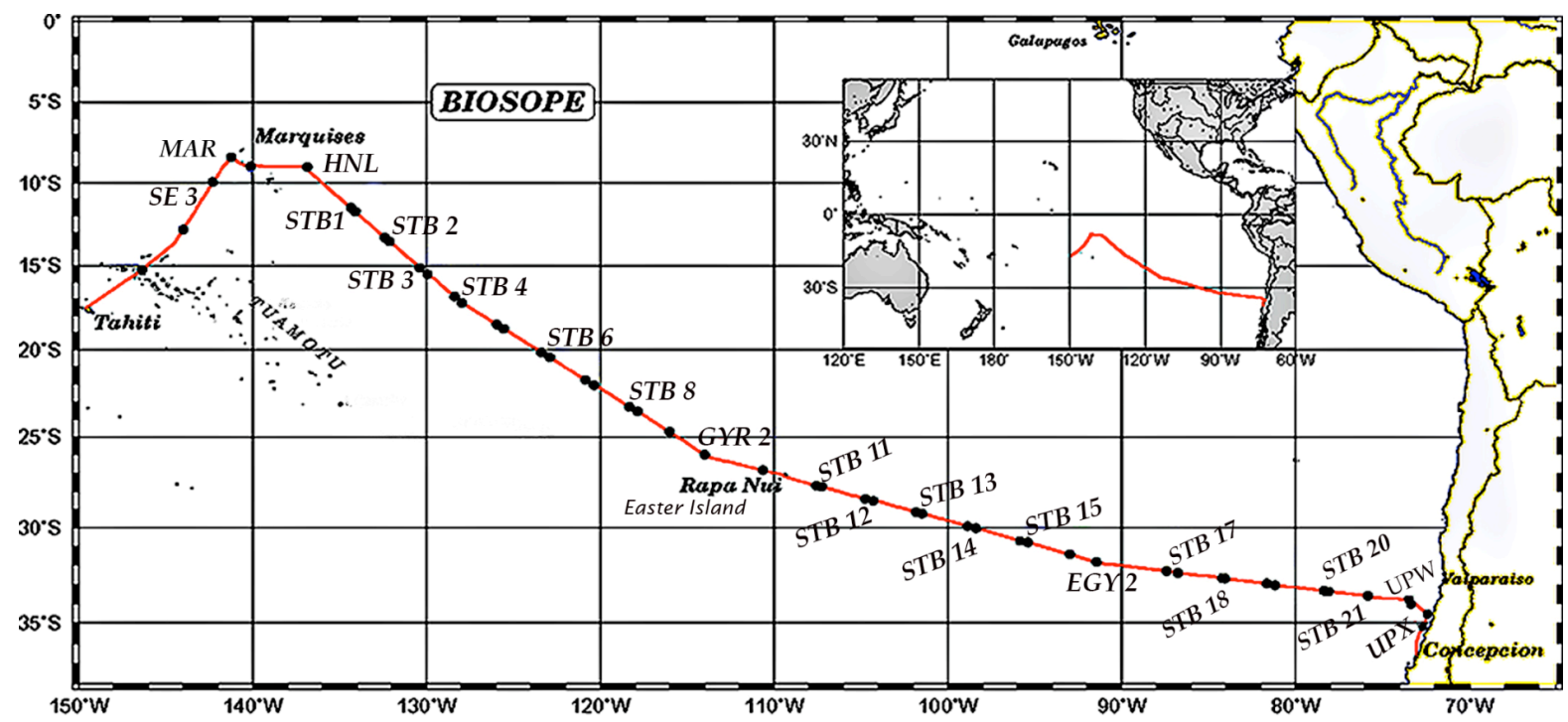

Fig. 1. BIOSOPE cruise track showing stations at which samples for tintinnid ciliates were obtained. Station locations and sampling dates are given in Table 1.

Here we examine patterns of community assembly across the SE Pacific. The areas sampled included zones with highest recorded species richness of tintinnids (>100 spp, for some stations in Kofoid and Campbell (1939)). The SE Pacific ranges from the clearest waters of the world ocean (Morel et al., 2007) to the productive upwelling system of Chile. Using data from stations across a large geographic scale and range of phytoplankton concentrations, the questions addressed were: 1) Is diversity related to resource level? 2) Are taxonomic and morphological diversity linked across large scales and species pools? 3) Is resource (phytoplankton) size-structure related to tintinnid community structure under low resource conditions? 4) What factors are controlling community assemblies? The questions were addressed by estimating diversity metrics of tintinnid communities, defined as sets of species occurring in a particular place and time (Fauth et al., 1996), both taxonomic and morphological, at each of the 22 stations sampled. Phytoplankton concentrations and composition were estimated using pigment analysis. Species abundance plots were constructed and compared to modeled distributions representing distinct patterns of species assemblies. The different model species abundance distributions are associated with different assumptions about the ecological equivalence of species and factors regulating the occurrence and abundance of individual species. The neutral model in which site-specific interactions and ecological differences between species are relatively unimportant was compared to models in which resource monopolization or species-interactions control community composition.

\section{Methods}

\subsection{Tintinnid sampling and sample analysis}

Station locations, sampling dates and depth strata sampled are given in Table 1. The cruise track is shown in Fig. 1. For tintinnids, usually 6 depths were sampled between the surface and just below the chlorophyll maximum depth (based on CTD fluorescence profiles) using a 201 Niskin bottle. At each station, 5-101 volumes of sample from each depth (total volumes for each station are given in Table 1) was concentrated to $20 \mathrm{ml}$ by slowly and gently pouring the water through a $20 \mu \mathrm{m}$ mesh Nitex screen fixed to the bottom of a $10 \mathrm{~cm}$ dia. PVC tube. We have found that using a $20 \mu \mathrm{m}$ concentrator yields higher numbers of tintinnids than settling whole water samples, in agreement with Pierce and Turner (1994), and have used the method in previous studies (Cariou et al., 1999; Dolan and Gallegos, 2001). Concentrated water samples were fixed with Lugol's solution (2\% final conc.). Aliquots $(2-10 \mathrm{ml})$ of concentrated sample were settled in sedimentation chambers and subsequently, the entire surface of the chamber was examined using an inverted microscope at 200x total magnification. All material from all the samples was examined.

Tintinnid identifications were made based on lorica morphology and following Kofoid and Campbell $(1929,1939)$, Hada (1938) and Marshall (1969). Species of certain genera are known to be capable of displaying different lorica morphologies (e.g., Gold and Morales, 1976; Davis, 1981; Laval-Peuto, 1983; Wasik, 1988; Williams et al., 1994). We adopted a what we term a 'conservative' approach, that is pooling apparent varieties. However, only a 
few of the 149 species encountered in this study appeared potentially variable and may, or may not, represent single species (Dadayiella ganymedes-bulbosa-acuta, Tintinnopsis rapa-parva, Favella spp., Climacocylis spp). Empty lorica were not enumerated. For each station, data from all samples were pooled. Average cell concentrations were calculated from total counts divided by total original water sample volumes. Concentrations in terms of carbon were estimated by 1) calculating lorica volumes for each species based on combinations of simple geometric forms (entire or fractional cylinders, cones, hemispheres), 2) converting lorica volume to carbon units using the empirical conversion factor $0.05 \mathrm{pg} \mathrm{C}$ per $\mu \mathrm{m}^{3}$ of lorica volume reported by Verity and Langdon (1984).

\subsection{Tintinnid diversity metrics}

Taxonomic diversity was estimated for each sample as the Shannon index (ln-based, e.g., Magurran, 2004) and species richness. Morphological diversity was estimated by placing species into size-classes of lorica oral diameter (LOD). Each species was assigned the average dimensions reported in Koifoid and Campbell (1929, 1939), Campbell (1942) and Marshall (1969). LOD is considered the most conservative characteristic of tintinnid loricas (Laval-Peuto and Brownlee, 1986). Size-class diameters were binned over $4 \mu \mathrm{m}$ intervals beginning with the overall smallest diameter encountered and continuing to the largest diameter encountered in a given sample. For each sample, morphological diversity was estimated as the number of size-classes occupied and a Shannon index of morphological diversity calculated using numbers and proportional importance of different sizeclasses (ln-based). Statistical relationships between diversity, concentration estimates, station occupation rates and morphological characteristics were examined using nonparametric Spearman Rank Correlation.

\subsection{Tintinnid rank abundance curves}

We constructed log-rank abundance curves for the tintinnid assemblages of each station by calculating relative abundance for each species and ranking species from highest to lowest and plotting $\ln$ (relative abundance) vs. rank. Then, for each assemblage, we constructed hypothetical log-rank abundance curves that could fit the data by using parameters of the particular assemblage. We constructed curves for three different models of community organization: geometric series, log-series, and log-normal.

A geometric series distribution represents the result of the priority exploitation of resources by species arriving sequentially in a community (Whittaker, 1972), and is modeled by assuming that each species' abundance is proportional to a fixed proportion $p$ of remaining resources. Thus the relative abundance of the $i$ th species is $(1-p) p^{i-1}$. For the tintinnid samples we used the relative abundance of the most abundant species to estimate $p$. This differs from the approach recommended by Magurran (2004), which is to use the relative abundance $p_{i}$ of the lowest-ranked species to iteratively calculate $p$ in the equation: $p_{i}=(1-p) p^{i-1}$ where $i$ is species rank. We felt that this curve-fitting approach forces the fitted line for the predicted geometric series to not have a minimum relative abundance less than that of the rarest species and tests simply whether the logarithm of relative abundances follows a straight line with species rank. Our method is more consistent with the original hypothesized mechanism of the geometric series (Whittaker, 1972; MacArthur, 1972) which is that the relative abundance of the most dominant species is equal to the proportion of resources or niche space it utilizes and that all lower ranked species will use the same proportion of remaining resources or niche species.

A log-series distribution represents the result of random dispersal from a larger community, such as a metacommunity in Hubbell's neutral theory (Hubbell, 2001). In a community exhibiting a log-series distribution, species having abundance $n$ occur with frequency $\alpha x^{n} / n$, where $x$ is a fitted parameter and $\alpha$ is Fisher's alpha, a measure of species diversity that is independent of total community abundance. For a given community with $N$ total individuals and $S$ species, $x$ can be found (Magurran, 2004) by iteratively solving the following equation for $x: S / N=-\ln (1-x)(1-x) / x$ and then finding Fisher's alpha as $\alpha=N(1-x) / x$. For the tintinnid assemblages, we simply used the observed $S$ and $N$ for each sample to calculate $x$ and $\alpha$.

A log-normal species abundance distribution is thought to result from a large number of species of independent population dynamics with randomly varying (in either space or time) exponential growth, such that $N(i) \propto e^{r i}$ where $r_{i}$ is a random variable. Since $N(i)$ is a function of an exponential variable, $\ln (N(i))$ should be normally distributed (May, 1975). Alternatively, species in a community that are limited by multiple factors that act on population size in a multiplicative fashion should also exhibit a lognormal distribution of abundances. We calculated the expected lognormal species abundance distribution for each tintinnid sample by calculating the mean and standard deviation of $\ln$ (abundance) and generating three expected abundance distributions for the $S$ species in the sample using the lognormal distribution macro program in an Excel ${ }^{\circledR}$ spreadsheet. We then calculated the mean abundance for each species, ranked from highest to lowest, and then calculated relative abundance.

For each station assemblage, the observed rank abundance distribution was compared to these three hypothetical models using a Bayesian approach: an Akaike Goodness of fit test (Burnham and Anderson, 2002). In this test, an Akaike Information Criterion (AIC) was determined as the natural logarithm of the mean (sum divided by $S$ ) of squared deviations between observed and predicted $\ln$ (relative abundance) for all ranked $S$ species plus an additional term to correct for the number of estimated parameters, $k$ ( 1 for geometric 
series and 2 each for logseries and lognormal distributions): $(S+k) /(S-k-2)$. The lower the calculated AIC value, the better the fit. A difference of 1 in AIC corresponds roughly to a three-fold difference in fit, so this test statistic is sensitive enough for our data to judge the fit of the three different models.

\subsection{Phytoplankton pigment sampling and analysis}

Seawater samples from 10 depths at each station (except SE3 for which no samples were taken) were collected from the $12 \mathrm{~L}$ Niskin bottles of the rosette sampler. Volumes between 5.6 and $1 \mathrm{~L}$ (depending on the trophic conditions) were filtered onto $25 \mathrm{~mm} \mathrm{GF/F}$ filters, and the filters stored in liquid nitrogen at $-80^{\circ} \mathrm{C}$ until analysis on land. The samples were extracted in $3 \mathrm{~mL}$ methanol for a minimum of $1 \mathrm{~h}$, with filter disruption by ultra-sonication. The clarified extracts were injected onto an Agilent Technologies 1100 series High Performance Liquid Chromatography (HPLC) system equipped with a refrigerated auto sampler and a column thermostat, according to a modified version of the method described by Van Heukelem and Thomas (2001). Separation was achieved within 28 min during a gradient elution between a Tetrabutylammonium actetate:Methanol mixture (30:70) and 100\% methanol. The chromatographic column, a Zorbax-C8 XDB $(3 \times 150 \mathrm{~mm})$ was maintained at $60^{\circ} \mathrm{C}$. Chlorophyll $a$, divinyl chlorophyll $a$ and derived products were detected at $667 \mathrm{~nm}$ and the other accessory pigments at $450 \mathrm{~nm}$ using a diode array detector. (Detection limits for chlorophyll $a$ were $0.0001 \mathrm{mg} \mathrm{m}^{-3}$, injection precision was $0.4 \%$ ). The different pigments were identified using both their retention times and absorption spectra. Quantification involved an internal standard correction (Vitamin E actetate) and a calibration with external standards provided by DHI Water and Environment (Denmark).

Total chlorophyll $a$ (TChla) was assigned as the sum of chlorophyll $a$, divinyl chlorophyll $a$ and chlorophyllide $a$. Seven diagnostic pigments (DP) were used to divide the phytoplankton population quantitatively, relative to the TChla concentration, into three main size classes: picophytoplankton, nanophytoplankton and microphytoplankton using the following 4 equations according to Uitz et al. (2006):

(1) Pico (mg TChla.m $\left.\mathbf{m}^{-3}\right)=$ TChla $(0.86$ zeaxanthin +1.01 chlorophyll $b+1.01$ divinyl chlorophyll $b$ )/DP

(2) Nano (mg TChla.m $\left.\mathbf{m}^{-3}\right)=$ TChla (0.35 19'-butanoyloxyfucoxanthin + 1.27 19'hexanoyloxyfucoxanthin +0.60 alloxanthin)/DP

(3) Micro (mg TChla.m $\left.\mathbf{m}^{-3}\right)=$ TChla $(1.41$ fucoxanthin + 1.41 peridinin)/DP

(4) $\mathrm{DP}=(0.86$ zeaxanthin +1.01 chlorophyll $b+1.01 \mathrm{di}-$ vinyl chlorophyll $b+0.3519$ '-butanoyloxyfucoxanthin +1.27 19'-hexanoyloxyfucoxanthin +0.60 alloxanthin +1.41 fucoxanthin +1.41 peridinin)
Table 2. Tintinnid summary data. Data were pooled for each station. Thus, total number of tintinnids examined denoted by $\sum$ cells, average concentrations of cells and carbon equivalents were calculated by dividing station sums by original sample volumes (see Table 1).

\begin{tabular}{lccc}
\hline Station & $\sum$ cells & Cells $1^{-1}$ & $\mathrm{ng} \mathrm{Cl}^{-1}$ \\
\hline SE3 & 107 & 10.7 & 51 \\
MAR1 & 548 & 27.4 & 16 \\
HLN1 & 480 & 16 & 70 \\
STB1 & 235 & 7.8 & 29 \\
STB2 & 82 & 4.1 & 18 \\
STB3 & 105 & 4.2 & 24 \\
STB4 & 98 & 3.9 & 16 \\
STB6 & 101 & 3.5 & 4 \\
STB8 & 115 & 2.0 & 4 \\
GYR2 & 190 & 3.2 & 10 \\
STB11 & 53 & 2.1 & 4 \\
STB12 & 250 & 4.3 & 5 \\
STB13 & 324 & 5.4 & 21 \\
STB14 & 276 & 4.9 & 4 \\
STB15 & 235 & 3.9 & 13 \\
EGY2 & 354 & 6.6 & 37 \\
STB17 & 314 & 5.0 & 22 \\
STB18 & 376 & 7.0 & 158 \\
STB20 & 1670 & 28.7 & 73 \\
STB21 & 805 & 13.4 & 23 \\
UPW2 & 2540 & 42.3 & 216 \\
UPX2 & 665 & 17.1 & 50 \\
\hline & & & \\
\hline
\end{tabular}

Concentrations were integrated throughout the depth strata corresponding to that sampled for tintinnids. The size fractionated Chla concentrations (pico, nano and micro) transformed into \% total chlorophyll were used to estimate an index of the size-diversity of chlorophyll (Shannon index, lnbased). Statistical relationships were examined using nonparametric Spearman Rank Correlation. Pigment concentrations calculated using only data from the depths at which tintinnids were sampled gave very similar results. Here we present the pigment data based on all data available for the depth strata considered.

\section{Results}

\subsection{Concentrations across the transect}

Tintinnid and phytoplankton concentrations co-varied (Fig. 2). Average tintinnid concentrations ranged from about 2-42 cells $\mathrm{l}^{-1}$ and 4-216 $\mathrm{n} \mathrm{Cl}^{-1}$ (Table 2). Concentrations of chlorophyll similarly varied over about 2.5 orders of magnitude, ranging $0.08-1.7 \mu \mathrm{g} \operatorname{chl} a 1^{-1}$. Phytoplankton, based on pigment concentrations (Table 3), appeared to be roughly divided between pico-sized taxa and nano-sized 
Table 3. Summary of phytoplankton pigment data. Layer denotes segment $(\mathrm{m})$ of the water column sampled at 7-10 discrete depths (generally 9). CMD is the chlorophyll maximum depth (m) based on the chlorophyll vertical profile, $\sum \mathrm{Chl} a$ is the average chlorophyll $a$ concentration $\left(\mu \mathrm{gl}^{-1}\right)$ throughout the layer sampled. Total chlorophyll was partitioned into 3 size fractions (see methods); $p$ Chl $a, n \mathrm{Chl}, \mu \mathrm{chl}$ are, respectively, estimated average pico-sized, nano-sized and micro-size chlorophyll $a$ concentrations as \% total chlorophyll $a$ throughout the layer sampled. Phytoplankton samples were not taken for Station SE3.

\begin{tabular}{lcccccc}
\hline Station & Layer & CMD & $\sum$ Chl $a$ & $p$ Chl & $n$ Chl & $\mu$ Chl \\
\hline MAR1 & $4-80$ & 41 & 0.370 & 20.80 & 49.52 & 29.60 \\
HLN1 & $4-140$ & 79 & 0.191 & 57.53 & 33.64 & 8.82 \\
STB1 & $4-140$ & 100 & 0.165 & 55.45 & 35.98 & 8.61 \\
STB2 & $5-130$ & 100 & 0.137 & 62.20 & 31.62 & 5.18 \\
STB3 & $4-120$ & 120 & 0.115 & 65.69 & 29.25 & 5.06 \\
STB4 & $5-210$ & 158 & 0.113 & 62.44 & 32.14 & 5.42 \\
STB6 & $5-250$ & 190 & 0.076 & 59.76 & 34.34 & 5.90 \\
STB8 & $5-240$ & 209 & 0.079 & 53.34 & 39.73 & 6.93 \\
GYR2 & $5-270$ & 180 & 0.082 & 52.3 & 41.16 & 6.54 \\
STB11 & $5-300$ & 199 & 0.080 & 53.98 & 38.88 & 7.19 \\
STB12 & $4-280$ & 211 & 0.077 & 53.34 & 40.22 & 6.54 \\
STB13 & $5-230$ & 160 & 0.087 & 49.4 & 44.43 & 6.17 \\
STB14 & $5-230$ & 160 & 0.093 & 57.05 & 36.74 & 6.22 \\
STB15 & $5-175$ & 105 & 0.139 & 56.94 & 36.36 & 6.70 \\
EGY2 & $5-190$ & 80 & 0.143 & 50.93 & 42.67 & 6.40 \\
STB17 & $6-175$ & 95 & 0.138 & 34.99 & 52.62 & 12.40 \\
STB18 & $4-140$ & 50 & 0.153 & 39.49 & 48.53 & 12.00 \\
STB20 & $5-140$ & 40 & 0.247 & 46.00 & 38.78 & 15.20 \\
STB21 & $15-90$ & 51 & 0.413 & 25.64 & 50.76 & 23.60 \\
UPW2 & $3-50$ & 40 & 1.697 & 3.31 & 8.14 & 88.60 \\
UPX2 & $3-60$ & 3 & 0.716 & 45.27 & 7.61 & 47.10 \\
\hline
\end{tabular}

taxa, with a minor contribution of micro-sized taxa at all stations except for the Marquise Island (MAR1) and upwelling stations (UPW, UPX).

3.2 Relationships among tintinnid diversity metrics and phytoplankton pigment parameters

Each of the tintinnid diversity metrics employed, taxonomic or morphological, were correlated with at least one other metric (Table 4). For example, species richness was high at all stations, ranging from 19 to 40 species, and correlated with the number lorica size-classes and the Shannon index H'. Values of Fisher's alpha were correlated with those of H' as well as the diversity of LOD (oral size classes). In contrast, there were few relationships among tintinnid diversity metrics and phytoplankton parameters (Table 5). Tintinnid taxonomic diversity as H' or Fisher's alpha was positively related to the depth of the chlorophyll maximum (Fig. 3). Fisher's alpha was also negatively related to average chlorophyll concentration and tintinnid concentration. The depth of the chlorophyll maximum layer was negatively related to av-

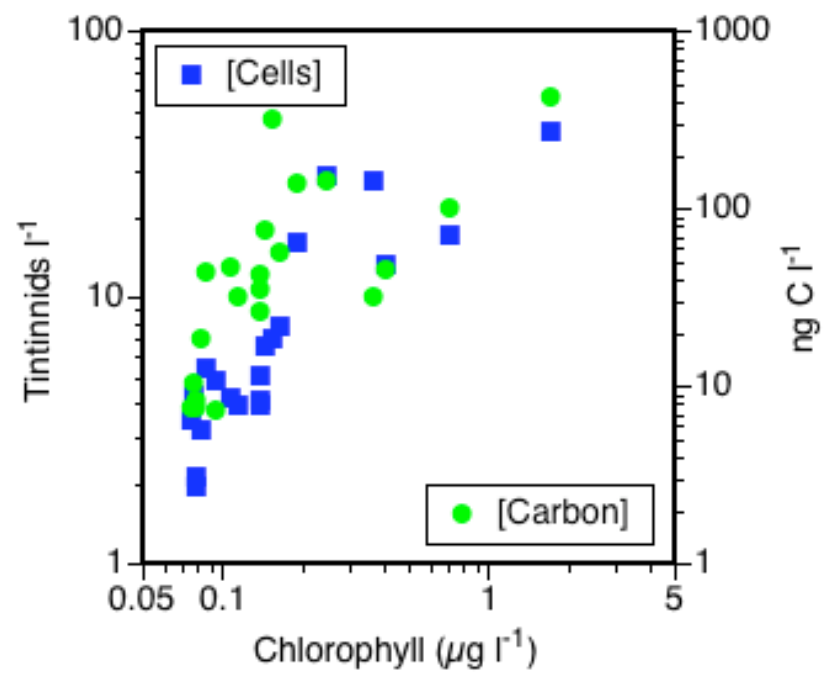

Fig. 2. Scatter plot of the relationship between phytoplankton concentration (as chlorophyll) and tintinnid ciliate abundance in terms of cells of carbon units among the stations. Data shown appears in Tables 2 and 3.

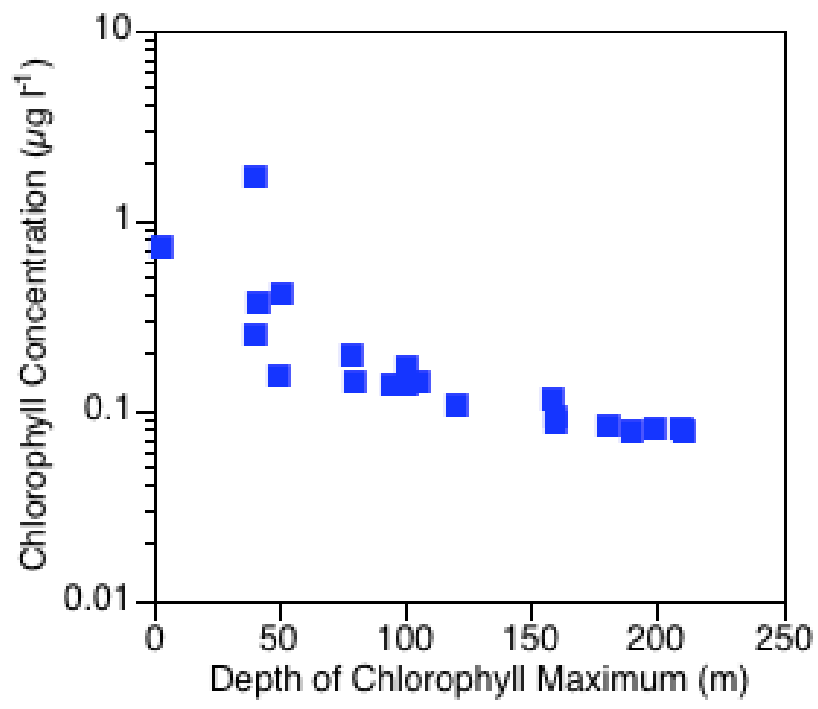

Fig. 3. Relationship between average chlorophyll concentration and the depth of the chlorophyll maximum layer among the stations sampled.

erage chlorophyll concentration (Table 3 and Fig. 4). Overall, tintinnid diversity appeared to be negatively related to resource availability as chlorophyll $a$ and positively related to resource dispersion, in the form of the depth of the chlorophyll maximum layer.

\subsection{Rank abundance distributions}

Results of the analyses of species abundance distributions are summarized in Table 6 and examples of observed and 
Table 4. Spearman rank correlation relationships (Rho values) among metrics of taxonomic and morphological diversity of tintinnids. For each station, estimates of taxonomic and morphological diversity were based on a pooled sample consisting of all individuals encountered in all samples from the station. Taxonomic metrics were numbers of species, the Shannon index, ln-based (H') and Fisher's alpha. Morphological metrics were numbers of lorica oral diameters (in $4 \mu \mathrm{m}$ size-classes) and the Shannon index of the diversity of lorica oral diameters (LOD-H'), calculated by substituting size-classes for species (see methods for details). For all pairs, $n=22$; asterisks denote significant relationships $(p=.01)$. Note that measures of taxonomic diversity and morphological diversity co-vary positively.

\begin{tabular}{lccccc}
\hline & \multicolumn{3}{c}{ Taxonomic } & \multicolumn{2}{c}{ Morphological } \\
\hline & \# species & H' & Fishers's alpha & \# LOD s-c & LOD H' \\
\hline \# species & - & $0.597^{*}$ & 0.318 & $0.727^{*}$ & 0.364 \\
H' & $0.597^{*}$ & - & $0.704^{*}$ & 0.396 & 0.550 \\
Fisher's alpha & 0.318 & $0.704^{*}$ & - & 0.176 & $0.596^{*}$ \\
\# LOD s-c & $0.727^{*}$ & 0.396 & 0.176 & - & 0.415 \\
LOD H' & 0.364 & 0.550 & $0.596^{*}$ & 0.415 & - \\
\hline
\end{tabular}

Table 5. Spearman rank correlation relationships (Rho values) among metrics of the diversity of tintinnids, their concentration and characteristics of the phytoplankton. For each station, estimates of taxonomic and morphological diversity were based on a pooled sample consisting of all individuals encountered in all samples from the station. Taxonomic metrics were numbers of species, the Shannon index, ln-based (H') and Fisher's alpha. Morphological metrics were numbers of lorica oral diameters (in $4 \mu \mathrm{m}$ size-classes) and the Shannon index of the diversity of lorica oral diameters (LOD-H'), calculated by substituting size-classes for species (see methods for details). Concentrations represent average water column integrated values. Chlorophyll $\mathrm{H}^{\prime}$, the phytoplankton size diversity parameter, reflects the relative contributions of micro, nano and pico-size cells to total chlorophyll. For all pairs, $n=21$; asterisks denote significant relationships $(p=.01)$. Overall, diversity appears negatively related to tintinnid and chlorophyll concentrations and positively related to the depth of the chlorophyll maximum layer which declines with chlorophyll concentration (see Table 3).

\begin{tabular}{lccccc}
\hline & \multicolumn{3}{c}{ Taxonomic } & \multicolumn{2}{c}{ Morphological } \\
\hline & \# species & H' & Fishers's alpha & \# LOD s-c & LOD H' \\
\hline log [tintinnids] & 0.189 & -0.195 & $-0.633^{*}$ & 0.250 & -0.208 \\
[chlorophyll] & 0.051 & -0.518 & $-0.709^{*}$ & 0.107 & -0.372 \\
chlorophyll H' & 0.071 & 0.335 & 0.386 & 0.195 & 0.320 \\
Depth Chl Max & 0.027 & $0.587^{*}$ & $0.785^{*}$ & -0.033 & 0.434 \\
\hline
\end{tabular}

modeled distributions shown in Fig. 5. There was no obvious relationship between the type of rank abundance distribution and phytoplankton or tintinnid concentrations. The geometric series, describing a sequential monopolization of resources, described well only one tintinnid assemblage, that of St 17 which was highly dominated by a single species of Eutintinnus. The log-series, resembling that predicted by Hubbell's neutral theory (Hubbell, 2001), provided the best match to the observed pattern in 17 of the 21 stations. The log-normal distribution, thought to result from complex species interactions, provided the best fit for 3 of the stations.

\section{Discussion}

In agreement with reports from survey campaigns (Kofoid and Campbell, 1929, 1939; Campbell, 1949) we found the tintinnid assemblages of the SE Pacific to be very speciesrich. Compared to recent geographic surveys of other areas, we recorded 149 species compared to a total of 87 tintinnid species found along a transect from $42^{\circ} \mathrm{N}$ to $42^{\circ} \mathrm{S}$ from Italy through the Indian Ocean to New Zealand (Modigh et al., 2003), or the 70-80 species recorded from west to east Mediterranean transects (Dolan et al., 2000, 2002). We found about 30 species per location and this taxonomic diversity was paired with morphological diversity. Chlorophyll concentrations were quite low and the phytoplankton was dominated by small cells, except for stations those in or near the upwelling zone (Table 3), consistent with expectations from similar areas of the Pacific (Mackey et al., 2002).

The relationships of diversity of these micrograzers and food resources were similar to those found examining trends across the Mediterranean in the late spring/early summer (Dolan, 2000). Total abundance of tintinnids increased with chlorophyll while diversity decreased. The depth of the chlorophyll maximum layer, inversely related to chlorophyll concentration, was positively related to tintinnid diversity 
Table 6. Results of analysis of the species abundance distributions. For the tintinnid community of each station, the log-rank abundance curve was compared to model-derived geometric, log normal and log-series curves using the Akaike test. Asterisks denote the lowest AIC value indicating the closest fit.

\begin{tabular}{lccccl}
\hline Station & $\log$ Normal & $\log$ Series & geometric & \# spp & Dominant sp (\% Ecells) \\
\hline MAR1 & -0.032 & $-1.199^{*}$ & 7.24 & 37 & Steenstrupiella steenstrupii $(29 \%)$ \\
HLN1 & $-1.29 *$ & 0.074 & 7.68 & 35 & Steenstrupiella steenstrupii $(22 \%)$ \\
STB1 & $-1.63^{*}$ & -0.603 & 8.06 & 40 & Proplectella perpusilla $(20 \%)$ \\
STB2 & -0.22 & $-1.02^{*}$ & 5.30 & 19 & Steenstrupiella gracilis $(37 \%)$ \\
STB3 & $-1.72^{*}$ & -1.24 & 7.23 & 31 & Cantheriella pyramidata $(25 \%)$ \\
STB4 & -0.61 & $-1.88^{*}$ & 7.08 & 21 & Salpingella attenuata $(15 \%)$ \\
STB6 & -0.36 & $-1.71^{*}$ & 8.89 & 22 & Steenstrupiella gracilis $(19 \%)$ \\
STB8 & -0.48 & $-2.05^{*}$ & 7.50 & 27 & Parundella aculeata $(17 \%)$ \\
GYR2 & -1.15 & $-2.09^{*}$ & 7.69 & 30 & Cantheriella pyramidata $(17 \%)$ \\
STB11 & -0.74 & $-1.69^{*}$ & 6.76 & 19 & Salpingella decurtata $(17 \%)$ \\
STB12 & -0.20 & $-0.54^{*}$ & 8.53 & 38 & Salpingella decurtata $(12 \%)$ \\
STB13 & -1.17 & -1.17 & 8.53 & 41 & Steenstrupiella steenstrupii $(14 \%)$ \\
STB14 & 0.63 & $-1.88^{*}$ & 8.00 & 36 & Salpingella curta $(18 \%)$ \\
STB15 & -1.00 & $-1.57^{*}$ & 6.34 & 38 & Salpingella faurei $(16 \%)$ \\
EGY2 & -1.33 & $-2.65^{*}$ & 6.42 & 38 & Protohabdonella striatura $(14 \%)$ \\
STB17 & 1.55 & 0.66 & $0.26 *$ & 19 & Eutintinnus apertus $(71 \%)$ \\
STB18 & 0.83 & $-1.39^{*}$ & 3.12 & 23 & Eutintinnus fraknoii $(50 \%)$ \\
STB20 & -1.54 & $-2.37^{*}$ & 4.59 & 29 & Protohabdonella curta $(26 \%)$ \\
STB21 & 1.40 & $-0.77^{*}$ & 4.64 & 18 & Protohabdonella curta $(31 \%)$ \\
UPW2 & -0.46 & $-1.03^{*}$ & 4.82 & 30 & Eutintinnus tubulosa $(39 \%)$ \\
UPX2 & 0.69 & $0.41^{*}$ & 6.15 & 32 & Condenellopsis pusilla $(47 \%)$ \\
\hline
\end{tabular}

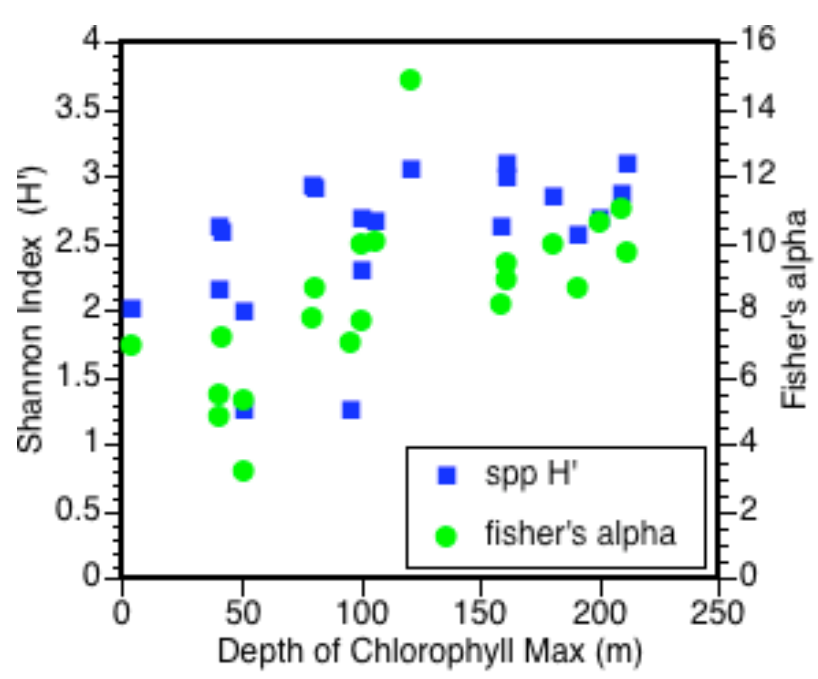

Fig. 4. Relationship between taxonomic diversity of the tintinnid community and the depth of the chlorophyll maximum layer.

(Dolan, 2000). In a subsequent study, based on samples taken at different stations in early fall from the Atlantic coast of Morocco to the Eastern Mediterranean, the only significant relationships found were between chlorophyll sizediversity and tintinnid diversity (Dolan et al., 2002). While in the SE Pacific average concentrations of chlorophyll encountered were of a range very similar to that reported in the Mediterranean transects, tintinnid abundances were lower by about half compared to the Mediterranean (Dolan, 2000; Dolan et al., 2002). The apparent variable relationships between tintinnid diversity and resources as chlorophyll led us to examine the patterns of species assembly using rank abundance distributions. The different patterns of rank abundance we examined as possibilities (geometric, $\log$-series and $\log$ normal) are thought to reflect different mechanisms governing the assemblage of individual communities. The distinct distributions thus reflect different assumptions concerning the ecological equivalence of species and factors regulating the abundance of individual species. Our goal was to determine which pattern dominated and if species abundance pattern was variable.

The geometric series represents a community in which dominant species limit the occurrence of rare species (e.g., May, 1975). The most abundant species monopolizes, in proportion to its abundance, part of the limiting resource; the second ranked species, in proportion to its abundance, monopolizes a part of the remaining resource, and so on, to the least abundant species. All resources are exploited and the total number of species is then largely controlled by the degree of dominance exerted by the most abundant species. The geometric pattern is found, for example, in the early 

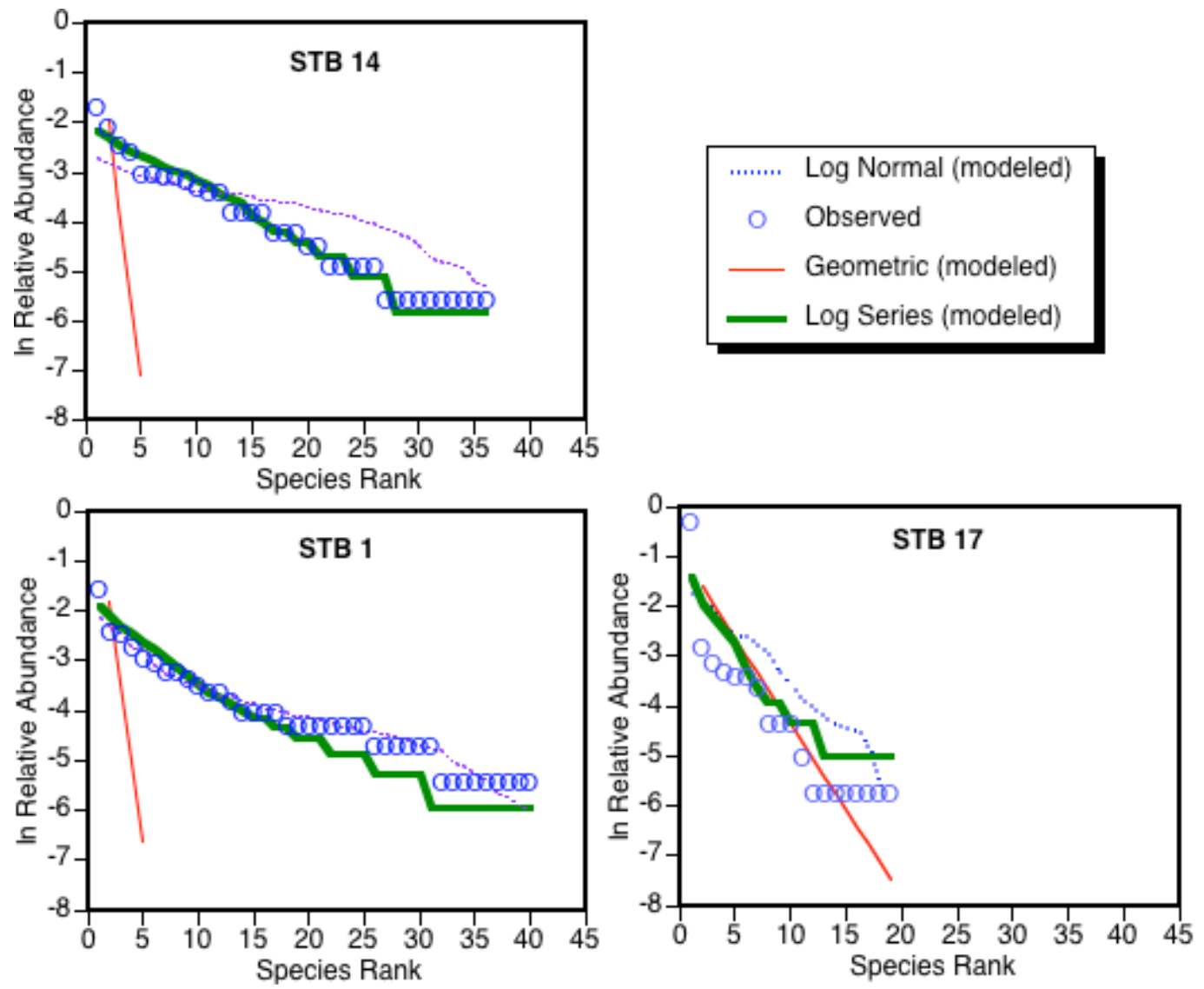

Fig. 5. Examples of species abundance distributions. Station STB 14 shows the most common pattern (15 of 21 data sets) of the log-series distribution providing the closest fit to the actual data. STB 1 was one of 3 data sets in which a log-normal distribution best matched the observed species abundance. STB 17, highly dominated by a single species (Table 4) was the only station for which the geometric distribution provided the closest fit.

successional stages among terrestrial plant communities or in relatively extreme environments (e.g. Whittaker, 1972).

A log-normal distribution represents a community in which populations are subjected to random variations or are affected by several interacting factors. It can result from a large number of species of independent population dynamics with randomly varying exponential growth, in either space or time (e.g., Huisman and Weissing, 1999). Alternatively, species in a community that are limited by multiple factors that act on population size in a multiplicative fashion should also exhibit a lognormal distribution of abundances. The lognormal species abundance distribution is the most common pattern exhibited by large assemblages (Magurran, 2004).

The log-series distribution of species abundance is predicted from Hubbell's neutral model. Local communities are part of a metacommunity, a larger widely dispersed (in space and time) group of trophically similar forms (Hubbell, 2001). With unlimited immigration, species abundance for a given community will resemble that of the larger metacommunity and will follow a log-series distribution (Magurran, 2004). Similar to the geometric series, ecological equiva- lence of species is assumed but in contrast dispersal plays a determining role. Log-series distributions characterize a large variety of organisms (e.g., Hubbell, 2001; Alonso et al., 2006). Among planktonic organisms, marine diatoms, a group of ecologically similar organisms, show log-series distributions, but not dinoflagellates, a group which includes autotrophic, heterotrophic and mixotrophic species (Pueyo, 2006).

The tintinnid communities of the SE Pacific were not welldescribed by a geometric series, as this model predicted a much more rapid than observed decline in relative abundance with decreasing rank than did either log-series or log-normal models. The single exception was a community a single species represented $71 \%$ of cell numbers (Table 4 ). The logseries models fit the data best (lowest AIC) in 17 of 21 cases, which suggests that tintinnid communities are structured by dispersal limitation and exhibit weak if any competition at other than local (perhaps $<1 \mathrm{~m}$ ) scales. The log-normal distribution fit the data best in 3 cases which were not obviously distinct in any manner from the other communities. 


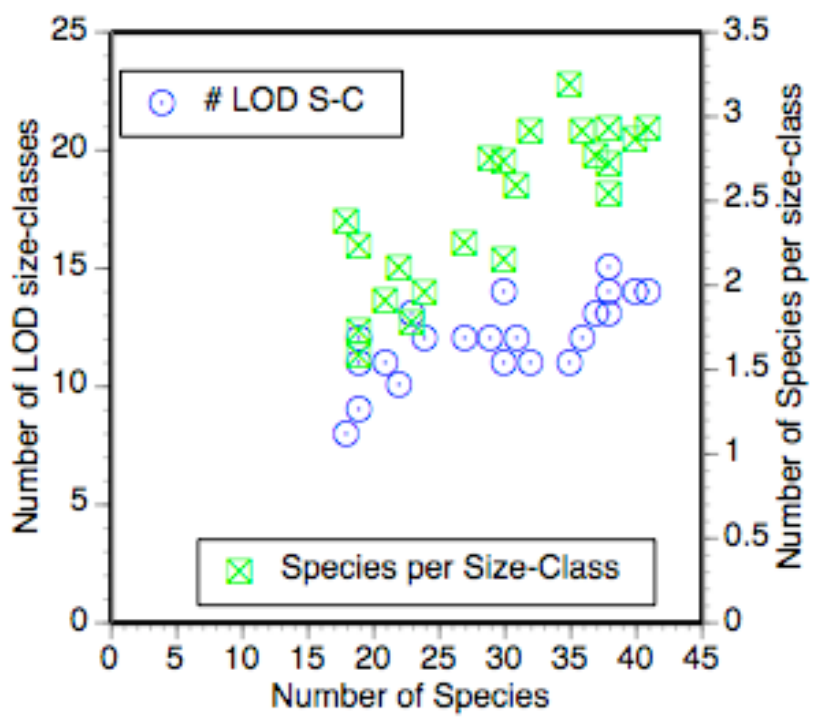

Fig. 6. Species packing in tintinnid communities across the SE Pacific Ocean. Comparing the different stations, both the number of mouth sizes, lorica oral diameter LOD in $4 \mu \mathrm{m}$ size - class intervals, and the average number of species per mouth size increased with the number of species.

Magurran (2004) has argued that species abundance distributions are difficult to compare for samples with less than 30 species, because small samples may represent a sampling of the right-hand "tail" of a lognormal distribution and therefore not detect species from the left-hand tail that are essentially "veiled" to the observer. However, we found that for communities with $<30$ species, the fit of the log-series distribution actually improved (AIC declined) as species richness increased. Although some station data may reflect partial samples of communities that are otherwise described best with a log-normal distribution, the consistent best fit of the $\log$-series distribution to the tintinnid data, particularly for communities with low total abundance and/or high species richness, could reflect the prevalence of mechanisms, such as neutral dispersal (Hubbell 2001), that lead to a log-series distribution.

The neutral model, due largely to its assumption of ecological equivalency among species within a community, has generated a great deal of controversy (for recent examples see Holyoak and Loreau, 2006; McGill et al., 2006; Alonso et al., 2006). There are differences of ecological significance between tintinnid species, for example LOD is related to the size of prey most efficiently grazed. However, in the SE Pacific competitive interactions may not be important simply because the food resources are insufficient or of the inappropriate size. Ritchie (1997) predicted theoretically that scarce food can lead to effective dispersal limitation rather than competition because each consumer population may not encounter all available food items within some specified time. Such a mechanism might explain why SE Pacific tintinnid communities appear to be random collections of species.
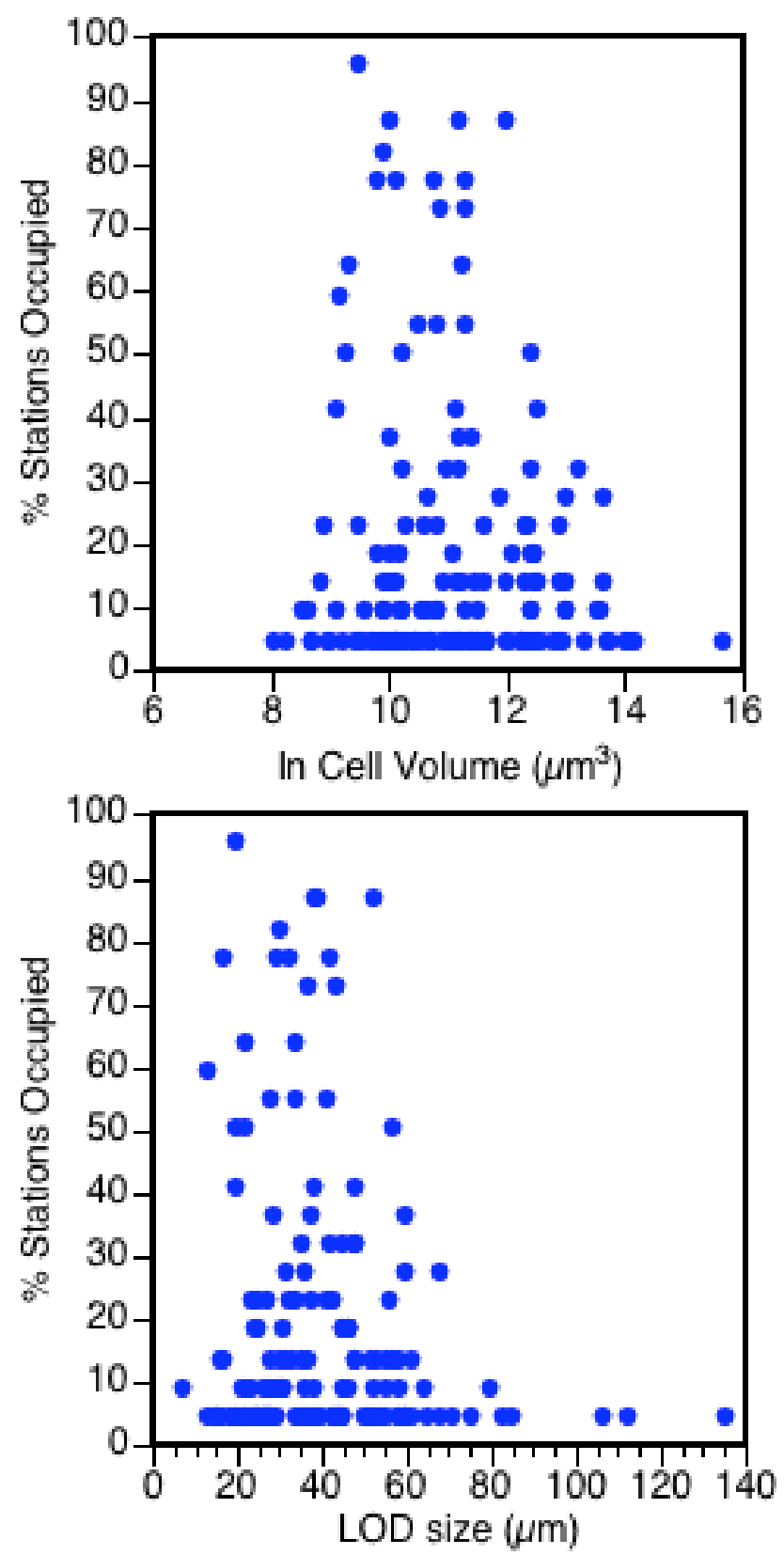

Fig. 7. Scatter plots of occurrence rates of tintinnid species, as a $\%$ of stations occupied, among the stations and morphological characteristics. The top panel shows the lack of relationship of occurrence rate and lorica volume (Rho value $=-0.003, p=0.97$ ) and the bottom panel shows a similar lack of relation with LOD size (Rho value $=-0.028, p=0.73$ ). Thus, neither lorica volume nor oral diameter appear linked to average occurrence.

To further test whether tintinnid communities are structured by resource partitioning versus dispersal in the SE Pacific, we examined the relationship between numbers of species in a community and numbers of distinct LOD sizeclasses composing the community and the number of species 


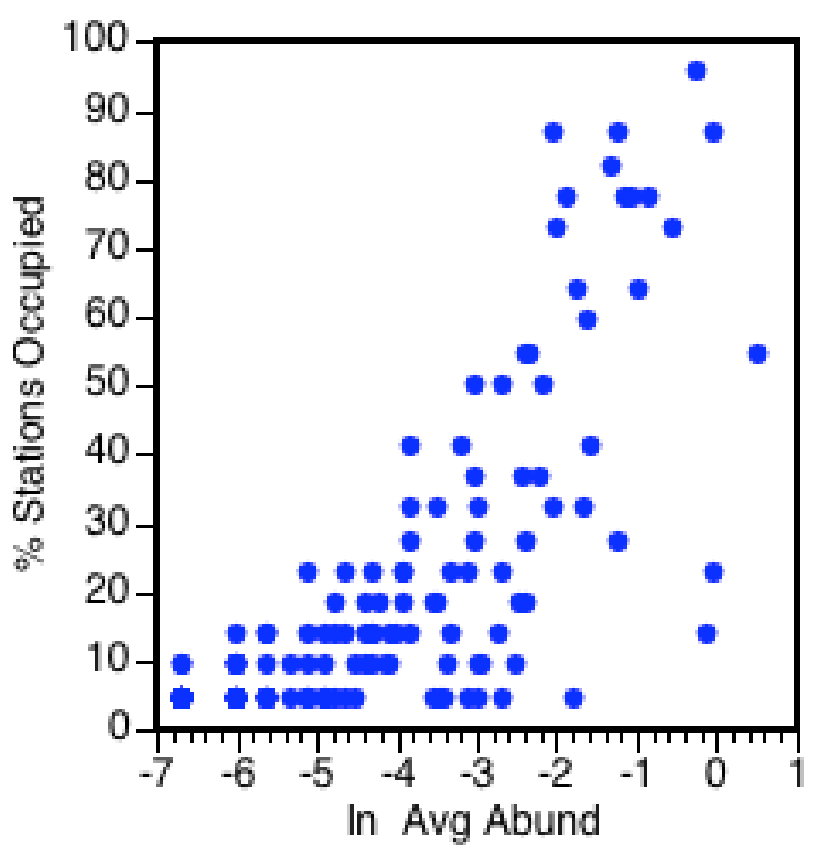

Fig. 8. Scatter plot of occurrence rate of tintinnid species, as a $\%$ of stations occupied, against average abundance across all the stations. The positive relationship between average abundance and occurrence (Rho value of $0.796, p<0.0001$ ) supports the idea that overall population size determines occurrence rate. Recall that morphology appears to be unrelated to occurrence rate (Fig. 7).

per LOD size-class within the community. We reasoned that if resource partitioning were strong, species-richness would reflect either larger ranges of allowed morphologies (more size-classes) or more species sharing the same resources (more species per size-class) but probably not both. We hypothesized that if species were added to communities at random, species-rich communities would exhibit both more size classes as well as more species per size class. Among the communities, we found that species numbers increase with numbers of distinct size-classes present and species per sizeclass of LOD (Fig. 6).

We also examined the importance of individual species characteristics in determining occurrence, by plotting occurrence rate, as \% stations occupied, against lorica volume or LOD for each species and found no relationships (Fig. 7). On the other hand, occupation rate was positively related to average abundance across all stations (Fig. 8). This last relationship is expected if occurrence of a species at a given site is dependent only on the large-scale population size of the species. The species with high occupation rates did not share any obvious morphological characteristics (Fig. 9). These species can be described as wide-spread, having all been found in both the Mediterranean and New Caledonia (Dolan, 2000; Dolan et al., 2006).

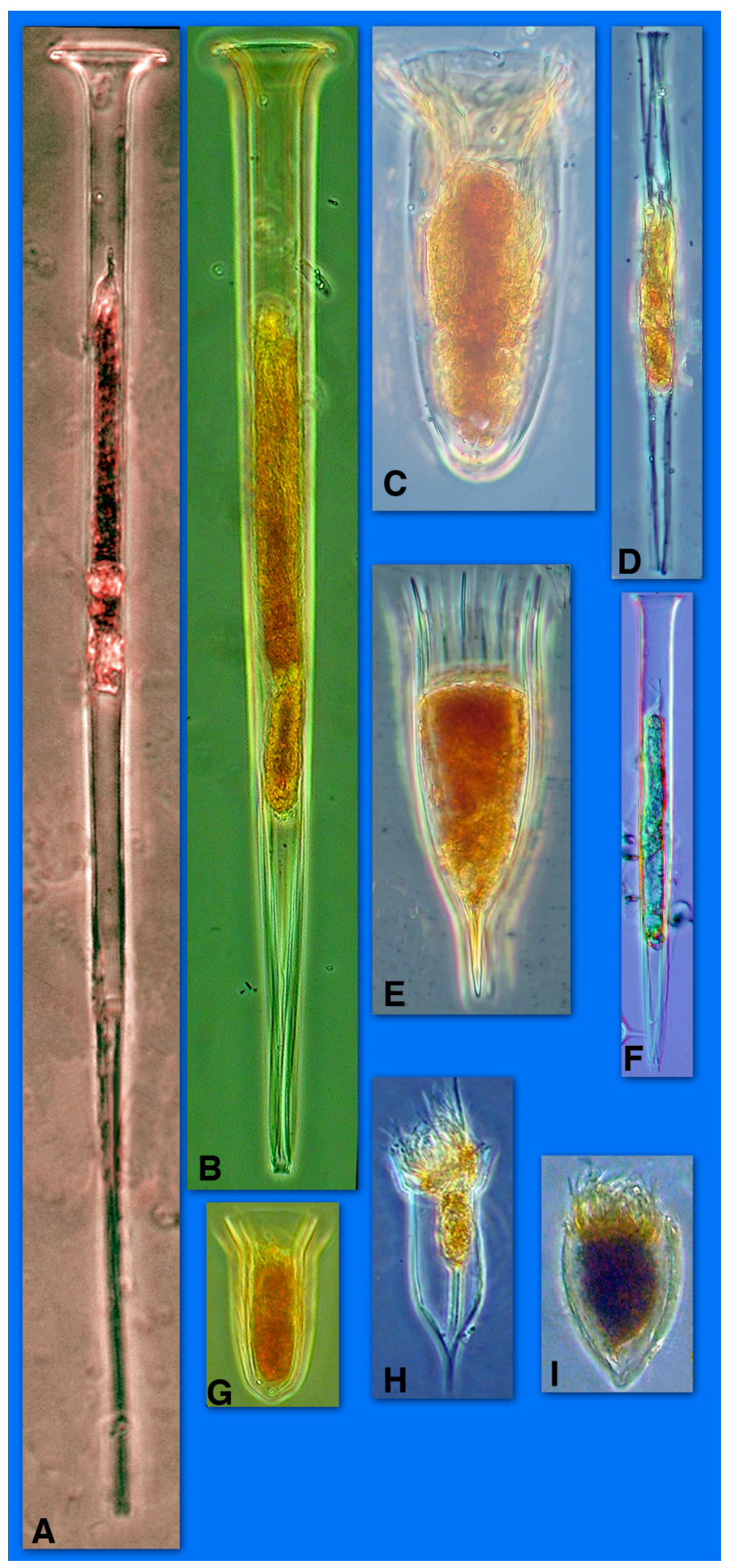

Fig. 9. Photomicrographs of tintinnid species found in over $75 \%$ of the stations sampled: Salpingella attenuata (A), Salpingella acuminata (B), Amphorella (Amphorides) quadrilineata (C), Salpingella faureii (D), Dadayiella ganymedes (E), Salpingella decurtata (F), Cantheriella pyrimidata (G), Ormsella trachelium (H), Protorhabdonella simplex (I). Dadayiella ganymedes (E) is $100 \mu \mathrm{m}$ in total length. Note that these wide-spread species do not share any obvious morphological characteristics. 
Overall we found evidence that tintinnid communities in the SE Pacific could be described by Hubbell's neutral theory. The patterns we found could be specific to the conditions we encountered of sparse resources combined with a large species pool. In this regard it is worth recalling that diversity increased among the stations with the depth of the chlorophyll maximum layer and decreased with the concentration of chlorophyll. High diversity was found with little food spread over a wide area coupled with low abundances of tintinnids, providing little opportunity for inter-specific relationships.

The neutral theory serves well as a null hypothesis when examining patterns of community composition. On the other hand, evidence supporting (as opposed to not disproving) dispersal limitation requires comparison of spatially distinct communities along some reasonable gradient with regard to dispersal (e.g. Condit et al., 2002). Our data for the SE Pacific do not permit an examination of actual dispersal using for example species decay. The stations sampled were across distinct water masses and current systems. In future investigations we hope to sample coherently within a single set of hydrological conditions (e.g., Thompson and Alder, 2005).

Our study re-visited a region and documented a surprising variety of forms, many of which were described from very few specimens and so whose existence could be doubted (Dolan, 2006). The correspondence of these forms with species is another question entirely. Cytological work on common coastal forms of Tintinnopsis suggests that there are likely about twice as many species catalogued (based on lorica morphology) as actually distinguishable via ciliary pattern (Agatha and Riedel-Lorjé, 2006; Laval-Pueto and Brownlee, 1986). Our data show that substituting morphological categories for classical species designations yields very similar results with regard to estimates of diversity or patterns of community assembly. Clearly, the next step is the use of genetic categories along with (or rather than) classical species designations, morphology will remains of interest as the means by which an organism interacts with its environment and other organisms.

\section{Conclusions}

Large numbers of tintinnid taxa were found, 18-41 species per station, with a total species pool of 149 . While, morphological and taxonomic diversity metrics of tintinnid communities co-varied they were not significantly related to phytoplankton diversity estimated using a pigment-based sizediversity metric. Taxonomic diversity of tintinnids, as H' or Fishers' alpha, was inversely related to chlorophyll concentration and positively to the depth of the chlorophyll maximum layer. The species abundance distributions compared to geometric, log-series and log-normal distributions showed that for most stations, the observed distribution most closely matched log-series, coherent with the neutral theory of ran- dom colonization from a large species pool. Occurrence rates of species were correlated with average abundance rather than specific characteristics of biomass or lorica oral diameter (mouth) size. Among stations, species richness was correlated with both the variety of mouth sizes (lorica oral diameters) as well as numbers of species per mouth size, also consistent with random colonization.

Acknowledgements. The samples for this work were taken by L. Garczarek and M. Viprey of the Roscoff Oceanic Plankton Group and we are truly grateful for it represented a large amount of work. The BIOSOPE cruise was admirably organized and managed by $\mathrm{H}$. Claustre and financed through the French national program "PROOF". Financial support was also provided by the Marplan project, part of the MARBEF Network of Excellence (Contract No. GOCE-CT-2003-505446). This is contribution MPS-07031 of MARBEF. The manuscript profited from the comments of the official reviewers (G. A. Thompson, G. B. McManus, G. Chust, X. Irigoien) as well as colleagues generous with their time (R. Colwell, B. McGill, B. Hawkins, T. Fenchel, J. Huisman, J. Henjes). However, we retain credit for all errors of fact and interpretation.

Edited by: W. Kiessling

\section{References}

Agatha, S. and Riedel-Lorjé, J. C.: Redescription of Tintinnopsis cylindrica, Daday 1887 (Ciliophora, Spirotricha) and unification of tintinnid morphology, Acta Protozool, 45, 137-151, 2006.

Agatha, S. and Stüder-Kypke, M. C.: Phylogeny of the order Choreotrichida (Ciloiophora, Spirotricha, Oligotrichea) as inferred from morphology, ultrastructure, ontogenesis, and $\mathrm{SSr}$ RNA gene sequences, Eur. J. Protistol., 43, 37-63, 2007.

Agatha, S., Strûder-Kypke, M. C., Beran, A., and Lynn, D. H.: Pelagostrobilidium neptuni (Montagnes and Taylor, 1994) and Strombidium biarmatum nov. spec. (Ciliophora, Oligotrichea): phylogenetic position inferred from morphology, ontogenesis, and gene sequence data, Eur. J. Protistol., 41, 65-83, 2005.

Alonso, D., Etienne, R. S., and McKane, A. J.: The merits of neutral theory, Trends Ecol. Evol., 21, 451-457, 2006.

Beers, J. R. and Stewart, G. L.: Microzooplankters in the plankton communities of the upper waters of the eastern tropical Pacific, Deep-Sea Res., 18, 861-883,1971.

Burnham K. P. and Anderson D. R.: Model selection and multimodel inference: a practical information-theoretic approach, Springer, New York, 2002

Campbell, A. S. : The Oceanic Tintinnoina of the plankton gathered during the last cruise of the Carnegie, Carnegie Institution of Washington, Washington D.C., Publication 537, 1942.

Cariou, J. B., Dolan, J. R., and Dallot, S.: A preliminary study of tintinnid diversity in the NW Mediterranean Sea, J. Plank. Res., 21, 1065-1075, 1999.

Condit, R., Pitman, N., Leigh, E. G., Chave, J., Terbough, J., Foster, R. B., Nunez, P. B., Aguilar, S., Valencia, R., Villa, G. MullerLandau, H. C., Losos, E., and Hubbell, S. P.: Beta-diversity in tropical forest trees, Science, 295, 666-669, 2002. 
Davis, C. C.: Variations of lorica shape in the genus Ptychocylis (Protozoa: Tintinnia) in relation to species identification, J. Plank. Res., 3, 433-443, 1981.

Dolan, J. R.: Tintinnid ciliate diversity in the Mediterranean Sea: longitudinal patterns related to water column structure in late spring-early summer, Aquat. Microb. Ecol., 22, 20-30, 2000.

Dolan, J. R.: Re-discovered beauty - new images for old descriptions - tropical tintinnids of the genus Xystonellopsis (Ciliophora, Tintinnia), Protist, 157, 251-253, 2006.

Dolan, J. R. and Gallegos, C. L.: Estuarine diversity of tintinnids (planktonic ciliaters), J. Plank. Res., 23, 1009-1027, 2001.

Dolan, J. R. and Marassé, C.: Planktonic ciliate distribution relative to a deep chlorophyll maximum: Catalan Sea, N.W. Mediterranean, June 1993, Deep-Sea Res. 1, 42, 1965-1987, 1995.

Dolan, J. R., Claustre, H., Carlotti, F., Plounevez, S., and Moutin. T.: Microzooplankton diversity: relationships of tintinnid ciliates with resources, competitors and predators from the Atlantic coast of Morocco to the eastern Mediterranean, Deep-Sea Res. I, 49, 1217-1232, 2002.

Dolan, J. R., Jacquet, S., and Torréton, J.-P.: Comparing taxonomic and morphological biodiversity of tintinnids (planktonic ciliates) of New Caledonia, Limnol. Oceanogr., 51, 950-958, 2006.

Fauth, J. E., Bernardo, C., Camara, M., Resetarits, W. J., Van Burskik, J., and McCollim, S. A.: Simplifying the jargon of community ecology: a conceptual approach, Am. Nat., 147, 282286, 1996.

Gold, K. and Morales, E. A.: Studies on the sizes, shapes, and the development of the lorica of agglutinated tintinnida, Biol. Bull., 150, 377-392, 1976.

Hada, Y.: Studies on the Tintinnoinea from the Western Tropical Pacific, J. Fac. Sci. Hokkaido Imper. Univ. Ser. IV Zool., 6, 87190, 1938.

Hasle, G. R.: A quantitative study of phytoplankton from the equatorial Pacific, Deep-Sea Res., 6, 38-59, 1959.

Heinbokel, J. F.: Studies on the functional role of tintinnids in the Southern California Bight. II. Grazing rates of field populations, Mar. Biol., 47, 191-197, 1978.

Holyoak, M. and Loreau, M.: Reconciling empirical ecology with neutral community models, Ecology, 87, 1370-1377, 2006.

Hubbell, S. R.: The unified neutral theory of biodiversity and biogeography, Princeton, USA, Princeton University Press, 2001.

Huisman, J. and Weissing, F. J.: Biodiversity of plankton by species oscillations and chaos, Nature, 402, 407-410, 1999.

Karayanni, H., Christaki, U., Van Wambeke, F., Denis, M., and Moutin, T.: Influence of ciliated protozoa and heterotrophic nanoflagellates on the fate of primary production in the northeast Atlantic Ocean, J. Geophys. Res-Oceans, 110(C7), C07S1, doi:10.1029/2004JC002602, 2005.

Kofoid, C. A and Campbell, A. S.: A conspectus of the marine and fresh-water ciliata belonging to the suborder tintinnoinea, with descriptions of new species principally from the Agassiz expedition to the eastern tropical Pacific 1904-1905, Univ. Calif. Publ. Zool., 34, 1-403, 1929.

Kofoid, C. A. and Campbell, A. S.: The Tintinnoinea of the eastern tropical Pacific, Bull. Mus. Compar. Zool. Harvard Coll., 84, 1473, 1939.

Laval-Peuto, M.: Sexual reproduction in Favella ehrenbergii (Ciliophora, Tintinnia): taxonomic implications, Protistologica, 19, 503-512, 1983.
Laval-Peuto, M. and Brownlee, D. C.: Identification and systematics of the tintinnia (Ciliophora): evaluation and suggestions for improvement, Ann. Inst. Océanogr. Paris, 62, 69-84, 1986.

Lynn, D. H. and Small, E. B.: Phylum Ciliophora, in: An illustrated guide to the protozoa, edited by: Lee, J. J., Leedale, G. F., and Bradbury, P., Lawrence, USA, Society of Protozoologists, 371656, 2002.

MacArthur, R. H.: Geographical Ecology: Patterns in the Distribution and Abundance of Species, Harper and Row, New York, 1972.

Mackey, D. J., Blanchot, J., Higgins, H. W., and Neveux, J. : Phytoplankton abundances and community structure in the equatorial Pacific, Deep-Sea Res. II, 49, 2561-2582, 2002.

Magurran, A. E.: Measuring Biological Diversity, London, UK, Blackwell Publishing, 2004.

Marshall, S. M.: Protozoa, order Tintinnia, Conseil International pour l'Exploration de la Mer, Copenhagen, Denmark, CIEM, Fiches d'Indentification de Zooplancton, fiches, 117-127, 1969.

May, R. M.: Patterns of species abundance and diversity, in: Ecology and evolution of communities, edited by: Cody, M. L. and Diamond, J. M, Boston, USA, Harvard University Press, 81-120, 1975.

McGill, B. J., Maurer, B. A., and Weiser, M. D.: Empirical evaluation of neutral theory, Ecology, 87, 1411-1423, 2006.

Modigh, M., Castalado, S., Saggiomo, M., and Santarpia, I.: Distribution of tintinnid species from $42^{\circ} \mathrm{N}$ to $43^{\circ} \mathrm{S}$ through the Indian Ocean, Hydrobiologia, 503, 251-262, 2003.

Morel, A., Gentili, B., Claustre, H., Babin,M., Bricaud, A., Ras, J., and Tièche, F.: Optical properties of the "clearest" natural waters, Limnol. Oceanogr., 52, 217-229, 2007.

Pierce, R. W. and Turner, J. T. : Plankton studies in Buzzards Bay, Massachusetts, USA. IV. Tintinnids, 1987 to 1988, Mar. Ecol. Prog. Ser., 112, 235-240, 1994.

Pueyo, S.: Diversity: between neutrality and structure, Oikos, 112, 392-405, 2006

Leising, A. W., Gentleman, W. C., and Frost, B. W.: The threshold feeding response of microzooplankton within Pacific highnitrate low-chlorophyll ecosystem models under steady and variable iron input, Deep-Sea Res. II, 50, 2877-2894, 2003.

Ritchie, M. E.: Population dynamics in a landscape context: sources, sinks, and metapopulations, in: Wildlife and Landscape Ecology, edited by: Bissonette, J. A., Springer, New York, USA, 160-184, 1997.

Snoeybos-West, O. L. O., Salcedo, T., McManus, G. B., and Katz, L.: Insights into the diversity of choreotrich and oligotrich ciliates (class Spirotrichea) based on genealogical analyses of multilpe loci, Int. J. Syst. Evol. Microbiol., 52, 1901-1913, 2002.

Thompson, G. A. and Alder, V. A.: Pattern in tintinnid species composition and abundance in relation to hydrological conditions of the southwestern Atlantic during austral spring, Aquat. Microb. Ecol, 40, 85-101, 2005.

Uitz, J., Claustre, H., Morel, A., and Hooker, S: Vertical distribution of phytoplankton communities in open ocean: an assessment based on surface chlorophyll, J. Geophys. Res., 111, C08005, doi:10.1029/2005JC003207, 2006.

Van Heukelem, L. and Thomas, C. S.: Computer-assisted highperformance liquid chromatography method development with applications to the isolation and analysis of phytoplankton pigments, J. Chromatogr. A, 910, 31-49, 2001. 
Verity, P. G.: Abundance, community composition, size distribution, and production rates of tintinnids in Narragansett Bay, Rhode Island. Est. Coast. Shelf Sci., 24, 671-690, 1987.

Verity, P. G. and Langdon, C.: Relationships between lorica volume, carbon, nitrogen, and ATP content of tintinnids in Narragansett Bay, J. Plank. Res., 6, 859-868, 1984.

Wasik, A.: Antarctic tintinnids: their ecology, morphology, ultrastructure and polymorphism, Acta Protozool., 37, 5-15, 1988.
Williams, R., McCall, H., Pierce, R. W., and Turner, J. T.: Speciation of the tintinnid genus Cymatocylis by morphometric analysis of the loricae, Mar. Ecol. Prog. Ser., 107, 263-272, 1994.

Whittaker, R. H.: Evolution and measurement of species diversity, Taxon, 21, 213-251, 1972. 